\title{
Polyunsaturated Fatty Acids in Male Ruminant Reproduction - A Review
}

\author{
Len Van Tran", ${ }^{1, *}$ Bilal Ahmad Malla², Sachin Kumar², and Amrish Kumar Tyagi²
}

* Corresponding Author: Len Van Tran Tel: +84-0978852947, Fax: +84-0733850247,

E-mail: Lentranvan@sac.edu.vn

${ }^{1}$ Southern Agricuture College, My Tho City, Tien Giang, Vietnam

2 Division of Dairy Cattle Nutrition, National Dairy Research Institute, Karnal, Haryana-132001, India

Submitted Dec 15, 2015; Revised Jan 23, 2016; Accepted Feb 29, 2016

\begin{abstract}
Fatty acids such as n-3 and n-6 polyunsaturated fatty acids (PUFA) are critical nutrients, used to improve male reproductive performance through modification of fatty acid profile and maintenance of sperm membrane integrity, especially under cold shock or cryopreservation condition. Also, PUFA provide the precursors for prostaglandin synthesis and can modulate the expression patterns of many key enzymes involved in both prostaglandin and steroid metabolism. Many studies carried out on diets supplemented with PUFA have demonstrated their capability to sustain sperm motility, viability and fertility during chilling and freezing as well as improving testis development and spermatogenesis in a variety of livestock species. In addition to the type and quantity of dietary fatty acids, ways of addition of PUFA to diet or semen extender is very crucial as it has different effects on semen quality in male ruminants. Limitation of PUFA added to ruminant ration is due to biohydrogenation by rumen microorganisms, which causes conversion of unsaturated fatty acids to saturated fatty acids, leading to loss of PUFA quantity. Thus, many strategies for protecting PUFA from biohydrogenation in rumen have been developed over the years. This paper reviews four aspects of PUFA in light of previous research including rumen metabolism, biological roles, influence on reproduction, and strategies to use in male ruminants.
\end{abstract}

Keywords: Male Reproduction; Polyunsaturated Fatty Acids; Sperm Membrane; Sperm Quality; Semen Extender

\section{INTRODUCTION}

A high male fertility is essentially desirable in ruminant industry to get high quality semen for successful artificial insemination. Since semen quality plays a vital role in higher farm economic profit through the enhancement of conception rate and total annual number of animals born for each herd. Semen quality is however, influenced by many factors such as genetics, management, environment and nutrition. Fatty acids serve as source of energy and are critical components of the physical and functional structure of cells [1]. Polyunsaturated fatty acids (PUFA) such as linoleic acid (LA, 18:2n-6), alpha-linolenic acid (ALA, C18:3n-3), eicosapentaenoic acid (EPA, C20:5n-3), and docosahexaenoic acid (DHA, C22:5n-3) may target reproductive tissues and alter reproductive function and fertility [2].

Mammalian sperm contains very high proportion of PUFA [3-6], especially DHA and docosapentaenoic acid (DPA, 22:5n-3), with species-specific variability in fatty acid contents [7]. Membrane lipid composition of spermatozoa is correlated to specific functions, because it promotes the creation of microdomains with different fluidity and permeability characteristics [8], required for reaching and fusing with the oocyte [9]. Also, lipid composition of the sperm plasma membrane is a major determinant of mobility characteristics, cold sensitivity, overall viability [10] and membrane integrity [11]. It has been known that PUFA play a key role in the sperm mem- 
brane fluidity and susceptibility to lipid peroxidation [9]. The n-3 and n-6 PUFA are essential for the reproductive activity representing about $30 \%$ to $50 \%$ of total fatty acid amount in the membrane of mammal spermatozoa [4] and contribute to regulate fluidity and acrosome responsiveness. Rooke et al [12] noted that an increase of n-3 and n-6 PUFA in the pig sperm membrane from diets resulted in improved spermatozoa characteristics. Similar results were found in bovine sperm $[13,14]$, goat sperm $[15]$ and ram sperm $[16,17]$, those who demonstrated that the inclusion of PUFA in diets caused the change of fatty acid composition of sperm membrane and increased the quality of fresh or post thawing sperm. Meanwhile, several studies have focused on improving sperm quality in male ruminants by adding PUFA to semen extenders, to reduce sperm cell damage in cooled semen [18], to improve the fatty acid composition and quality of cooled and frozen-thawed sperm $[19,20]$. There are, however, conflicting results among these studies. The probable reasons are due to the variation in type and quantity of dietary fatty acids, especially n-3 and n-6 PUFA as well as difference in PUFA composition of semen and spermatozoa in various species. Lipid and fatty acid composition of sperm cells differ not only for different species $[21,22]$ but also for different animals $[4,23]$. Differences in PUFA composition of sperm may influence the flexibility and compressibility of the sperm membrane [24]. Such properties may affect the ability of the plasma membrane to accommodate the characteristic flagella motion of the sperm [25]. This paper describes the ruminal PUFA metabolism, its role in male ruminant reproduction and takes comprehensive look at the influence of addition of PUFA to diet or extender on the alteration of sperm membrane fatty acid composition and the sperm quality (motility, viability, membrane integrity) as well as the development of testis and sexual hormonal production, simultaneously also points out some necessary strategies to use PUFA more effectively in ruminants.

\section{LIPID AND POLYUNSATURATED FATTY ACIDS METABOLISM IN RUMEN}

Early studies of ruminal lipid metabolism were concerned primarily with the fate of fatty acids as they passed through the rumen and were exposed to the microbial population [26-28]. Results from these studies indicated that there are two major processes that occur in the rumen, hydrolysis of ester linkages in lipids and biohydrogenation of the unsaturated fatty acids.

In ruminants, when dietary lipids enter the rumen, the initial process in lipid metabolism is the hydrolysis of the ester linkages found in triglycerides, phospholipids, and glycolipids. Dietary lipids are extensively hydrolyzed in the rumen by enzymes such as lipases, galactosidases and phospholipases [29], produced by bacteria and protozoa, resulting in the formation of free fatty acids and glycerol with little accumulation of mono- or di-glycerides $[26,30]$. Glycerol is fermented rapidly, yielding propionic acid as a major end product [31]. Although the extent of hydrolysis is generally high $(>85 \%)$, but number of factors affect the rate and extent of hydrolysis. For example, the extent of hydrolysis is reduced as the dietary level of fat is increased [32] or factors such as low rumen $\mathrm{pH}$ and ionophores inhibit the activity and growth of bacteria $[33,34]$.

Biohydrogenation of unsaturated fatty acids is the second transformation that dietary lipids can undergo in the rumen. Hydrogenation occurs on free fatty acids, thus it is necessary that lipolysis has taken place previously and factors that affect hydrolysis also impact biohydrogenation. Unsaturated fatty acids have relatively short half-lives in ruminal contents because they are rapidly hydrogenated by microbes to more saturated end products. The first step in rumen biohydrogenation typically involves an isomerization of the cis- 12 double bond to a trans- 11 configuration resulting in a conjugated di- or trienoic fatty acid [35]. Next is a reduction of the cis-9 double bond resulting in a trans-11 fatty acid. The final step is a further hydrogenation of the trans-11 double bond producing stearic acid or C18:1 trans-15 [29]. The end-product of hydrogenation of C18 FA is stearic acid. However, when large amounts of n-6 PUFA are available, hydrogenation generally stops before this final step, leading to various cis and trans isomers of monoenoic fatty acid [36]. The most important is trans-vaccenic acid (C18:1).

Most biohydrogenation ( $>80 \%$ ) occurs in relation to the fine food particles and this is attributed to extracellular enzymes of bacteria either associated with the feed or free in suspension [35]. The rate of rumen biohydrogenation of fatty acids is typically faster with increasing unsaturation and LA ( $\mathrm{n}-6$ PUFA) and linolenic acids (n-3 PUFA) are the major substrates for this process. For most diets, n-6 PUFA and n-3 PUFA are hydrogenated to the extent of $70 \%$ to $95 \%$ and $85 \%$ to $100 \%$, respectively [32,37]. This extensive level of hydrogenation is reduced when diets high in concentrates are fed, which can be attributed to inhibition of lipolysis at the low $\mathrm{pH}$ that is typically observed on these diets [33]. Hydrogenation is also adversely affected when excessive unprotected fatty acids are present in the diet. Therefore, the development of proper strategies for protecting these essential fatty acids from ruminal degradation is very necessary.

\section{BIOLOGICAL ROLES OF LIPID AND POLYUNSATURATED FATTY ACIDS IN RELATION TO MALE REPRODUCTION}

\footnotetext{
Essential component of sperm cell membrane

Lipids can be divided into two major groups namely simple and complex lipids depending on the types of products produced upon hydrolysis. Simple lipids are those which yield one or two hydrolysis products per molecule namely, tri- di- and monoglycerides, free and esterified cholesterol and free fatty acids $[38,39]$. Complex lipids are dominated by phospholipids which possess a phosphoric acid derivative condensing with one of the
} 
-OH groups of the molecule instead of a fatty acid [40]. The phosphate group may join to a variety of alcohols to produce the following very critical constituents of animal cell membranes which include phosphatidyl inositol, phosphatidyl serine, phosphatidyl choline, phosphatidyl ethanolamine, and sphingomyelin. Phosphatidyl choline is also commonly known as lecithin and phosphatidyl ethanolamine, phosphatidyl serine and phosphatidyl inositol as cephalins. Viability and motility of spermatozoa depends on the integrity of the mitochondrial sheath, of which phospholipids are a major component. If fatty acids in these phospholipids are oxidized by free oxygen radicals, spermatozoa will be damaged [41] and their motility will be impaired [42].

Phospholipids contain high levels of PUFA with phosphatidyl ethanolamine, phosphatidyl choline and phosphatidyl serine functioning as important constituents of cell membranes [43]. Phospholipids have also been implicated in creating the charge on the plasma membrane with sphingomyelin, phosphatidyl choline and phosphatidyl ethanolamine being neutral and phosphatidyl inositol, phosphatidyl serine and cardiolipin possessing a net negative charge. This poses significant differences in charge between the monolayers of the plasma membrane $[40,44]$. Phospholipid content accounts for the highest ratio in total lipid of spermatozoa and varies among species (Table 1). The phospholipid content of water buffalo spermatozoa and seminal plasma is $0.548 \mathrm{mg} / 10^{9}$ cells and $0.594 \mathrm{mg} / \mathrm{mL}$, respectively whereas these values in bull are $0.416 \mathrm{mg} / 10^{9}$ and $1.491 \mathrm{mg} / \mathrm{mL}$, respectively [5].

Previous research works showed that there is considerable difference in fatty acid profile of sperm cell membrane. In most mammals, DHA (C22:6n-3) is the dominant PUFA, although, in several species, DPA (C22:5 n-3) predominates. Jain and Anand [5] observed that buffalo spermatozoa contained nearly equal distribution of saturated (47.8\%) and unsaturated (49.8\%) fatty acids and there were high levels of PUFA. More than 70 percent of the total unsaturated fatty acids were PUFA, mainly DHA (C22:6n-3) except in the neutral lipids where it was arachidonic acid (C20:4n-6). Paulos et al [47] reported that proportion of unsaturated fatty acids were quite high (71\%) in ram spermatozoa. Among these unsaturated fatty acids, DHA was also predominant with 56 percent. In contrast, goat spermatozoa have very high proportion ( $w / w, 67 \%)$ of saturated fatty acid chains linked to the phospholipid fractions [48]. While there is a very low proportion of C22:5n-3 (2\%) and C22:6n-3 (4\%) fatty acids and the major unsaturated fatty acids are C18:1n-9 and C18:2n-6. In general, the PUFA composition of spermatozoa are the derivatives of linoleic (C18:2n-6) and linolenic (C18:3n-3) acids which are normally present in the diet and are converted into their long-chain derivatives by a series of elongation and desaturation reactions (Figure 1). More interestingly, percentage of essential fatty acids and PUFA in reproductive tissue such as sperm membrane can be modified with diets [13-16].

\section{Energy source for sperm activity}

Sperm activity is its ability to move or swim in semen or reproduction tract in female, which needs a lot of energy supply. Fructose has been known as major source of energy for sperm activity. Nevertheless, phospholipids are probably used for energy production in spermatozoa in the absence of oxidisable soluble carbohydrate [50]. An investigation performed by Hartree and Mann [51] revealed that incubation of ram semen in the absence of any exogenous substrate, resulted in spermatozoa oxidising the long chain fatty acid resides from phosphatidyl choline which is a principal phospholipid of spermatozoa. Lardy and Phillips [52] suggested that in the absence of carbohydrate, bull spermatozoa appeared to derive their energy from the oxidation of intracellular phospholipid, as the phospholipid content of washed bull spermatozoa decreases markedly on aerobic incubation [3].

\section{Contribution to production of male sexual hormone and capacitation ability of sperm}

Steroids include cholesterol, derived sterols and sex hormones. Free cholesterol and phospholipids comprised around $80 \%$ of sperm lipids [53]. Cholesterol is the most important sterol of animal cell membranes [39] and acts as a key substrate for the testosterone biosynthesis of leydig cells from the testis interstitial tissues, which regulate reproductive activities in male animals including spermatogenesis, secondary sexual characteristics, behavior effects and metabolic effects. Cholesterol also plays a crucial function in altering spermatozoa plasma membrane permeability/fluidity, which may affect its capacitation and fertilization. Cholesterol efflux from sperm membrane causes changes in its architecture, increased bilayer permeability and fluidity that give rise to the capacitated state of the sperm cells [54]. According to Kadirvel et al [55], the event of cholesterol efflux directly or indirectly alters the membrane fluidity and permeability, leads to increased intracellular calcium concentration, which may induce

Table 1. Lipid content and composition of spermatozoa (Komarek et al [45]; Scott [46])

\begin{tabular}{lccccc}
\hline \multirow{2}{*}{ Species } & \multicolumn{4}{c}{ Distribution of lipids in some species (\%) } \\
\cline { 2 - 6 } & Total lipid $\mathbf{~ m g / g}$ cells & Phospholipids & Cholesterol esters & Triglycerides & Diglycerides \\
\hline Bull & 25.2 & 73.4 & 14.3 & 3.2 & 6.4 \\
Boar & 25.0 & 74.8 & 12.8 & 42 & 7.9 \\
Stallion & 29.1 & 58.6 & 23.2 & 140 & 9 \\
Human & 20.0 & 66.0 & 14.0 & 2.0 & 20 \\
Fish (trout) & 22.0 & 75.0 & 18.0 & & 1.0 \\
\hline
\end{tabular}




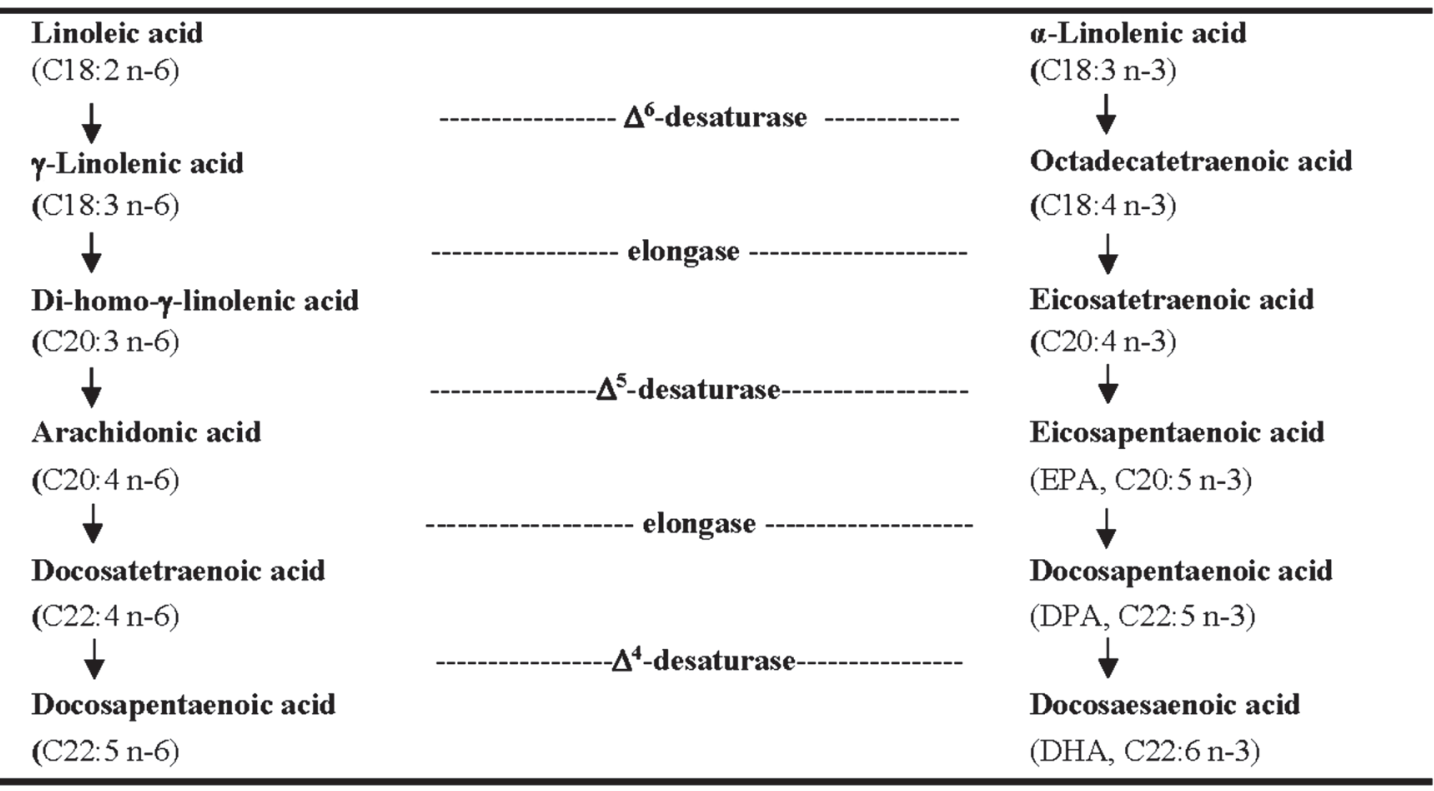

Figure 1. The metabolic pathways of $n-6$ and n-3 families of polyunsaturated fatty acids (Lenzi et al [49]).

capacitation-like changes in frozen-thawed buffalo spermatozoa. The cholesterol content in spermatozoa and seminal plasma of water buffalo is $22.2 \%$ and $24.7 \%$ of total neutral lipids while these ratios in bull are $23.3 \%$ and $18.8 \%$; respectively [5].

PUFA which are concentrated in the head and tail membrane regions of spermatozoa have been shown to play an important role in both sperm capacitating and the interaction between spermatozoa and uterine surface environment [53]. Moreover, PUFA are associated with fatty acids and cholesterol synthesis through gene expression. It has been known that the steroidogenic acute regulatory (StAR) protein regulates the rate-limiting step in steroid biosynthesis, for example, the transport of cholesterol from the outer to the inner mitochondrial membrane during the process of testosterone synthesis [56]. PUFA such as arachidonic acid and its metabolites affect steroidogenesis via direct effects on StAR gene. Impact of PUFA on reducing expression of genes involved fatty acid and cholesterol synthesis via binding and inactivating UBXD8; an endoplasmic reticulum (ER) membranebound protein that facilitates the degradation of insulin induced gene, which normally sequesters the sterol regulatory element binding protein (SREBP) cleavage activating protein (SCAP)SREBP complex in the ER and prevents its activation; thereby inhibiting proteolytic processing of SREBP1 and resulting in alteration of fatty acids and cholesterol synthesis. PUFA also act as ligands for peroxisome proliferator activated receptors (PPARs), which are transcription factors of members of the superfamily of nuclear hormone receptors including receptors for steroid hormone. Activation of PPAR a by PUFA leads to stimulation of fatty acid catabolism [56,57].

Provision of precursors for synthesis of prostaglandins
Both n-3 and n-6 PUFA provide the precursors for prostaglandin (PG) synthesis and can modulate the expression patterns of many key enzymes involved in both prostaglandin and steroid metabolism. There is considerable evidence that PUFA are capable of influencing biosynthetic pathways involved in both prostaglandin synthesis and steroidogenesis $[7,58]$, which have multiple roles in the regulation of animal's various functions including reproduction [53]. The linoleic (C18:2n-6) acid is converted to arachidonic (C20:4n-6) acid, which is a precursor for the 2-series of prostaglandins $\left(\mathrm{PGE}_{2}, \mathrm{PGF}_{2 \alpha}\right.$ etc.), whereas the linolenic (C18:3n-3) acid is converted to EPA, a precursor of the 3-series of prostaglandins $\left(\mathrm{PGE}_{3}, \mathrm{PGF}_{3 \alpha}\right.$ etc.). Also, EPA can be elongated and desaturated to DHA, which is not a precursor for prostaglandin synthesis, but is an important component of membranes [7]. The proportion of different PUFA in the diet alters cell membrane phospholipid composition and this becomes quantitatively significant because the precursors of each group of PGs compete for the same enzyme systems for metabolism [59].

Prostaglandin E and 19-hydroxy-prostaglandin E are related to sperm motility [53]. Among PGs, $\mathrm{PGF}_{2 \alpha}$ is known as a key hormone playing an important role in male reproduction. $\mathrm{PGF}_{2 \alpha}$ acts directly on the contractile tissues of the testicular coats and epididymis causing an increased rate of sperm passage from the epididymis to the deferent ducts [60]. Several experiments in vitro demonstrated that use of $\mathrm{PGF}_{2 \alpha}$ may increase the number of sperm in a collection by enhancing sperm movement from the epididymis to the deferent duct, where they are available for ejaculation [61], or causes a prolongation of concentration of the luteinizing hormone (LH) and testosterone in bull [62]. Also, Olfati et al [63] revealed that $\mathrm{PGF}_{2 a}$ could be used to enhance spermatozoa numbers in the ejaculate of Arkhar-Merino cross- 
bred ram semen in the non-breeding season. Ram seminal plasma is rich in $\mathrm{PGF}_{2 \alpha}$ and this hormone has been shown to be of importance to sperm transport in the ewe's cervical canal [64].

\section{EFFECT OF POLYUNSATURATED FATTY ACIDS ON PRODUCTION OF HORMONE AND TESTIS DEVELOPMENT}

Fatty acids are components of the phospholipid layer of cell membranes and may affect the membrane property and interactions between membrane components [12]. In males, activity of reproductive system involves the hypothalamic-pituitary-testicular axis, which controls hormones involving testicular development and spermatogenesis. It has been shown that PUFA $[65,66]$ or their derived eicosanoids $[67,68]$ has a straight relation with this axis. Hence, the effects of dietary PUFA on the secretion of gonadotropin-releasing hormone (GnRH), LH, and follicle stimulating hormone (FSH), and the responsiveness of these cells to hormonal production, may be worthy of investigation [69].

Esmaeil et al [70] investigated the effects of several dietary fatty acids on semen quality and blood parameters in rams supplemented with $35 \mathrm{~g}$ per day by palm oil (high in C16:0), sunflower oil (high in C18:2 n-6) and fish oil (high in EPA 20:5 n-3 and DHA 22:6n-3). Results showed that rams which received fish oil had the total highest testosterone concentration in the blood $(11.3 \mathrm{ng} / \mathrm{mL})$ compared with those fed sunflower oil (10.8 ng/ $\mathrm{mL})$ and palm oil $(10.2 \mathrm{ng} / \mathrm{mL})$ during the experiment. This finding indicated that fish oil (high in n-3 PUFA) supplementation in diet possibly affected phospholipid composition in plasma membranes of the testes, altered the expression and affinity of gonadotropin receptors and influenced the rate of testosterone synthesis. In contrast, dietary soybean oil (high in C18:2 n-6) and fish oil supplementation at level of $2 \%$ dry matter (DM) to control did not significantly affect the testosterone concentration among treatments in male growing kids [15]. However, fish oil diet significantly elevated the testicular growth measurements (circumference, volume, width, and length), seminiferous tubule and lumen diameter, leydig cell, sertoli cell, spermatogonia cell, and spermatocyte cell counts as well as absolute fresh testis masses at slaughter compared to control or soybean oil diets. This indicated fish oil diet, high in n-3 PUFA, had positive influence on gonad development and when dietary DHA level increased, better gonad development could be observed. It is likely that the incorporation of n-3 PUFA from fish oil diet affected the testis development through its impact on hypothalamo-pituitarygonadal axis. Based on previous data, there have been a lot of evidence approving the relationship of this axis with the testis development in male via the activity of FSH and LH. Hormone FSH is considered as the main mitogenic factor responsible for sertoli cell divisions $[71,72]$ and $\mathrm{LH}$ as main factor affecting differentiation and maturation of the leydig cell population [73]. According to Chandolia et al [74], GnRH treatment hastened the onset of puberty, increased sertoli cell counts, sperm output, and testicular weight. Bagu et al [75] concluded that treatment of bull calves with bFSH increased testicular growth, hastened onset of puberty, and enhanced spermatogenesis.

It has been suggested that insulin-like growth factor I (IGF-I) is one of the important factors for germ cell development, maturation and the motility of the spermatozoa [76]. A recent study focusing on improving the quality of buffalo spermatozoa by addition of IGF-I in vitro, Selvaraju et al [77] reported that IGF-I improved sperm viability and motility by acting as an antioxidant and maintaining functional membrane integrity. Interestingly, PUFA are known to be associated with IGF-I in regulation of testicular development. Fair et al [78] demonstrated that the high n-3 PUFA fish oil supplemented rams had higher IGF-I concentrations on week 9 (after feeding 64 days) compared with the control ram group adding saturated palmitic acid (PA). This finding agrees with Robinson et al [79], who reported PUFA feeding increased IGF-I level in body fluids of bovine. The most concerned issue here is whether IGF-I is produced by reproductive tissues or not and how PUFA influences the IGF-I production in these tissues, because the local production of IGF-I plays a major role in the growth of tissues [80], thereby may affect the proliferation of precursor Leydig cells (LCs), establishment of a normal number of adult LCs, and proper steroidogenesis [81]. The testis secretes IGF-I [82], the presence IGF-I in bovine seminal plasma (BSP) and the expression of IGF-I receptors in the spermatogonia, spermatocytes, spermatids, and spermatozoa was reported [83]. So far, the mechanism that PUFA may affect the IGF-I concentration in testis tissue has been not elucidated yet.

\section{EFFECT OF POLYUNSATURATED FATTY ACIDS SUPPLEMENTATION WAYS ON MODIFICATION OF MEMBRANE FATTY ACIDS AND QUALITY OF SPERMATOZOA}

\section{Polyunsaturated fatty acids added to semen extender}

Cryopreservation is known to produce a deleterious effect on the motility, viability and membrane status of spermatozoa [84]. PUFA are capable of modifying fatty acid profile of sperm membrane, thereby can affect sperm quality, especially under cold shock or cryopreservetion conditions [85]. Various studies conducted on different animal species to assess such impact of PUFA on sperm quality as it is directly added in semen extender (Table 2). However, effect of PUFA on sperm resistance to cooling and freezing procedures through change of membrane characteristics is controversial, and may be related to the type of PUFA content as well as compositions added to semen extender.

Abavisani et al [20] studied the potential protective effects of n-3 PUFA on bovine sperm quality in response to cooling and 
Table 2. Effect of supplementation with polyunsaturated fatty acids in semen extender on sperm quality

\begin{tabular}{|c|c|c|c|c|}
\hline Reference & Species & Fat source & Percent in extender & Effect \\
\hline Kandelousi et al [86] & Bull & $n-3,6,9$ fatty acids & $1 \%, 2.5 \%$, and $5.0 \%$ & $\begin{array}{l}\text { Non-improvement of the sperm motility in chilled storage condition } \\
\text { and after freezing-thawing }\end{array}$ \\
\hline Abavisani et al [20] & Bull & $\mathrm{n}-3$ fatty acid & $1 \%, 2.5 \%$, and $5.0 \%$ & $\begin{array}{l}\text { No improvement of sperm resistance to cooling and cryopreservation } \\
\text { sperm }\end{array}$ \\
\hline Kaka et al [87] & Bull & $\mathrm{n}-3$ fatty acid & $3,5,10$, and $15 \mathrm{ng} / \mathrm{mL}$ & Significantly improved sperm quality post-cooling and post-thawed \\
\hline Towhidi and Parks [19] & Bull & $\begin{array}{l}n-3 \text { fatty acid } \\
\text { and } a \text {-tocopherol }\end{array}$ & $\begin{array}{l}1,10,100 \mathrm{ng} / \mathrm{mL} \\
\text { and } 0.2,0.4 \mathrm{mM}\end{array}$ & $\begin{array}{l}\text { Changed the membrane fatty acids composition, and improved } \\
\text { freezablity of sperm. Increased DHA and the ratio of } n-3 \text { to } n-6 \text { fatty } \\
\text { acid in sperm both before freezing and after thawing }\end{array}$ \\
\hline Nasiri et al [88] & Bull & $\begin{array}{l}n-3 \text { fatty acid } \\
\text { and } a \text {-tocopherol }\end{array}$ & $\begin{array}{l}0.1,1,10 \mathrm{ng} / \mathrm{mL} \\
\text { and } 0.1,0.2 \mathrm{mM}\end{array}$ & $\begin{array}{l}\text { Increased DHA percentage before freezing and after thawing, } \\
\text { thereby improve cryosurvival of sperm via altering membrane lipid } \\
\text { composition }\end{array}$ \\
\hline Towhidi et al [89] & Ram & $\begin{array}{l}\text { n-3 fatty acid } \\
\text { and } \boldsymbol{\alpha} \text {-tocopherol }\end{array}$ & $\begin{array}{l}0.1,1,10 \mathrm{ng} / \mathrm{mL} \\
\text { and } 0.1,0.2 \mathrm{mM}\end{array}$ & $\begin{array}{l}\text { Significantly improved the in vitro characteristics of post-thawed } \\
\text { sperm }\end{array}$ \\
\hline
\end{tabular}

cryopreservation, three different concentration of omega-3 PUFA $(1 \%, 2.5 \%$, and $5 \%)$ in combination with polyethylene glycol were added to the semen extender. Results showed that no improvement of motility, viability of bovine sperm was observed after 24 and 48 hours of semen storage in cold and frozen-thawed conditions. Authors concluded that the addition of n-3 PUFA directly to semen extenders is not effective in protecting the sperm membrane in response to cooling and freezing. Similarly, Kandelous et al [86] observed the addition of omega-3, 6, 9 fatty acids to the basic extender did not enhance the resistance of the bovine sperm membrane to cooling and freezing-thawing and that further studies are required to find suitable candidate compounds that can boost the quality of semen that is chilled and freeze-thawed. Conversely, Kaka et al [87] reported that the addition of n-3 PUFA ( $5 \mathrm{ng} / \mathrm{mL}$ ) to Tris extender improved quality of frozen-thawed bull spermatozoa. The percentage of viable sperm and sperm with intact membrane was higher in treatment added to $5 \mathrm{ng} / \mathrm{mL}$ of $\mathrm{n}-3$ PUFA than four other groups to which $0,5,10$, and $15 \mathrm{ng} / \mathrm{mL}$ of $\mathrm{n}-3$ PUFA were added, respectively. In addition, concentration of n-3 PUFA and lipid peroxidation in post-thawed sperm was higher in all treated groups than control group. This finding indicated that the n-3 PUFA concentration added to semen extender is very important, which contributed to the improvement in total motility, viability and membrane functional integrity due to increase in membrane fluidity and resistance against cooling and freezing. However, at higher level of concentrations did not produce better sperm characteristics may be because of the presence of more fatty acids that make mammalian sperm susceptible to lipid peroxidation [90,91]. It is noteworthy that the effects of fatty acids on sperm quality may vary due to the sources of fatty acids, types of fatty acid and solvent used as well as the amount of fatty acids incorporated into the extender [86,87,92].

Mammalian spermatozoa are quite sensitive to lipid peroxidation, due to the phospholipid content of sperm membranes with their high PUFA side chains [90]. Seminal plasma provided some protection against peroxidation via its constituent anti- oxidants [93]. However, dilution of semen reduces antioxidant availability for sperm. Also, supplementing semen extender with PUFA during cryopreservation increases production of reactive oxygen species (ROS), which attack the double bonds of PUFA [94]. Therefore, the incorporation of an antioxidant into semen extender is beneficial [88].

In a trial conducted in Brown Swiss bulls, semen was divided into 12 groups including 4 levels of n-3 PUFA $(0,1,10,100 \mathrm{ng} / \mathrm{mL})$ and 3 levels of Vitamin E (0. 0.2, $0.4 \mathrm{mM})$, Towhidi and Parks [19] found that the incorporation $10 \mathrm{ng} / \mathrm{ml}$ of $\mathrm{n}-3$ PUFA into semen extender during cryopreservation increased DHA and the ratio of $n-3$ to n-6 PUFA in sperm before freezing and after thawing, resulting in a significant increase in motility and viability of sperm. The higher level of $\mathrm{n}-3$ fatty acids ( $100 \mathrm{ng} / \mathrm{mL}$ ) actually decrease post-thawed sperm quality. This finding indicated that $10 \mathrm{ng} / \mathrm{mL}$ was adequate quantity to protect sperm during cryopreservation in bulls. A decrease in sperm quality at $100 \mathrm{ng} / \mathrm{mL}$ of n-3 PUFA may be due to excess of PUFA actually promoting oxidation by contributing ROS that damage sperm membrane. In agreement with these data, optimal sperm quality after freezing and thawing was observed in extender that included $0.4 \mathrm{mM}$ vitamin E. Hence, the highest level of a-tocopherol might be more beneficial when a higher level of PUFA is supplemented. Overall, combining the optimal level of n-3 PUFA $(10 \mathrm{ng} / \mathrm{mL})$ with the highest level of vitamin $\mathrm{E}(0.4 \mathrm{mM})$ in semen extender changed the membrane lipid composition and improved freezability of sperm. This result is in agreement with studies in bulls by Nasiri et al [88] and in rams by Towhidi et al [89], who reported that semen extender added $10 \mathrm{ng} / \mathrm{mL}$ of $\mathrm{n}-3$ PUFA accompanied with vitamin $\mathrm{E}$ as an antioxidant at level of $0.2 \mathrm{mM}$ or $0.4 \mathrm{mM}$ could improve cryosurvival of sperm via altering sperm membrane lipid composition.

\section{Polyunsaturated fatty acids added to diet}

Gulliver et al [95] reviewed the role of n-3 PUFA on reproduction in sheep and cattle and suggested that direct feeding studies in ruminants to evaluate the effects of n-3 PUFA on male fertility 
are required. There have been a lot of studies performed in various species including ruminants and various reports have been published (Table 3). In general, PUFA are major component of the sperm cell membranes and thus the major mechanism that PUFA can affect the sperm quality is associated with membrane physiological characteristics. The incorporation of PUFA into diet is able to cause alteration of fatty acid profile of sperm plasma membrane and results in improved sperm quality. Kelso et al [6] reported that PUFA play a major role in the sperm's lipid metabolism, motility and ability to fuse with the oocyte. A decrease in percent of n-3 PUFA in sperm lipids is accompanied by a decrease in sperm number and motility in ejaculates of aged bulls. Other studies in Holstein bulls [99], goat bucks [53] and rams [16] showed the inclusion of $\mathrm{n}-3$ source in the daily diet improved the sperm quality either fresh or cryopreservation.

In the study carried out by Adeel et al [98] on Nili-Ravi buffalo bulls fed with three sources of fat (a balanced ration, a sunflower oil supplemented ration [SFO] and a whole sunflower seeds supplemented ration [SFS]) for 63 days indicated that inclusion of sunflower oil or whole sunflower seeds up to $1 \%$ of dry matter intake $(0.13 \mathrm{~kg}$ of fat per day) can safely be used for breeding buffalo bulls without any adverse effects on fresh and frozenthawed semen quality. Motility and plasma membrane integrity (hypo-osmotic swelling [HOS]) of post-thawed spermatozoa were higher in bulls fed the sunflower-enriched diets compared to control. This result indicated that SFO or whole SFS reduced the adverse effects of cryopreservation on sperm plasma membrane, which is supported by Khan and Ijaz [100], who reported that the damage to sperm plasma membrane mostly occurring during cryopreservation is one of the major reasons of reduced motility of frozen-thawed spermatozoa. This result is in agree- ment with Milovanov and Golubj [101], who observed feeding of soya bean oil, high in LA, improved post-thaw motility in rams.

Calisici [102] studied the effects of dietary supplementation of omega-3-fatty acids ( $800 \mathrm{~g} / \mathrm{d}$ coated alpha linolenic acid [ALA] and $400 \mathrm{~g}$ palmitic acid [PA]/d) on sperm quality of Holstein Friesian bulls before and after cryopreservation and found that feeding ALA increased the content of DHA in ALA bulls whereas the DHA content in PA bulls did not change. Recently, Moallem et al [13] studied the rate of incorporation of various dietary omega-3 fatty acids into bull sperm and the effects on the physiological parameters of fresh and frozen-thawed semen. Bull diets were supplemented with saturated fatty acid ( $360 \mathrm{~g} / \mathrm{d} / \mathrm{bull})$, flaxseed oil (450 g/d/bull providing $84.2 \mathrm{~g} / \mathrm{d}$ C18:3n-3) and fish oil (450 $\mathrm{g} / \mathrm{d} /$ bull providing $8.7 \mathrm{~g} / \mathrm{d} \mathrm{C} 20: 5 \mathrm{n}-3$ and $6.5 \mathrm{~g} / \mathrm{d}$ C22:6n-3). Results showed that the incorporation of $\mathrm{n}-3$ fatty acid into sperms was first expressed on the 6 th week of supplementation. Motility and progressive motility in frozen-thawed semen was higher in the flaxseed oil group than in the fish oil and saturated fatty acid groups ( $55.5 \%$ vs $50.9 \%, 47.7 \%$, and $43.4 \%$ vs $38 \%$, $37 \%$, respectively). Interestingly, this study indicated that in spite of the highest DHA content in the fish oil bulls, the improved sperm quality was lower in fish oil bulls than that in flaxseed bulls. According to Lyberg et al [103], DHA is highly sensitive to oxidation, thus, it might be that the high proportion of DHA in the sperm of fish oil (FO) bulls exceeded the optimal level for preventing oxidation damage, and therefore precluded the improvement in quality parameters of sperm in these bulls compared with that of the flaxseed oil group. Also, the ratio of n-6 to n-3 PUFA was significantly decreased in the fish oil supplemented bulls compared to saturated fatty acid and flaxseed oil group $(0.5 \%$ vs $1.01 \%$

Table 3. Effect of dietary polyunsaturated fatty acids enriched fat sources on semen quality

\begin{tabular}{|c|c|c|c|c|}
\hline Reference & Species & Fat source & Percent inclusion & Effect \\
\hline de Graaf et al [96] & Ram & Sunflower oil & $5 \%$ & No effect on motility, viability, acrosome integrity of sex-sorted sperm \\
\hline Samadian et al [16] & Ram & Fish oil & $3 \%$ & $\begin{array}{l}\text { Increased the proportion of DHA in sperm fatty acid composition, } \\
\text { improved sperm concentration and motility }\end{array}$ \\
\hline Jafaroghli et al [17] & Ram & Fish oil and Vit. C & $2.5 \%$ and $300 \mathrm{mg} / \mathrm{kg}$ & $\begin{array}{l}\text { Improved seminal quality, increased motility, HOS and percentage of } \\
\text { sperm with normal acrosome }\end{array}$ \\
\hline Esmaeili et al [70] & Ram & $\begin{array}{l}\text { Palm oil, sunflower oil, fish } \\
\text { oil }\end{array}$ & $35 \mathrm{~g} / \mathrm{d}$ & $\begin{array}{l}\text { Improved prefreezing semen characteristics after thawing, } 35 \text { days } \\
\text { after the removal of fatty acid source, the percentage of C } 22: 6 \text { was } \\
\text { highest in the fish oil treated group }\end{array}$ \\
\hline Alizadeh et al [97] & Ram & Fish oil and Vit. E & $2.5 \%$ and $0.5 \%$ & $\begin{array}{l}\text { Dietary FO had significant positive effects on all sperm quality and } \\
\text { quantity parameters compared with the control during the feeding } \\
\text { period }\end{array}$ \\
\hline Dolatpanah et al [53] & Goat & Fish oil and Vit. E & $2.5 \%$ and $0.3 \mathrm{~g} / \mathrm{kg} \mathrm{DM}$ & $\begin{array}{l}\text { Improved testes development enhanced the quality and quantity of } \\
\text { goat semen }\end{array}$ \\
\hline Fair et al [78] & Ram & Protected fish oil & $2 \%$ & $\begin{array}{l}\text { Increased semen concentration but no effect on other semen quality } \\
\text { parameters including semen volume, wave motion, and progressive } \\
\text { linear motion }\end{array}$ \\
\hline Adeel et al [98] & Buffalo & Sunflower oil, sunflower seed & $1 \%$ & $\begin{array}{l}\text { Improved the quality of sperm including motility and HOS of post- } \\
\text { thawed sperm }\end{array}$ \\
\hline Moallem et al [13] & Bull & Flaxseed oil, fish oil & $\begin{array}{l}450 \mathrm{~g} / \mathrm{d} \\
(84.2 \mathrm{~g} / \mathrm{d}(18: 3 \mathrm{n}-3)\end{array}$ & $\begin{array}{l}\text { Changed in the characteristics of both fresh and frozen-thawed } \\
\text { semen, increased motility and progressive motility of sperm }\end{array}$ \\
\hline
\end{tabular}


and $0.66 \%$ respectively). This finding is in agreement with [102]. Generally, the incorporation of DHA into sperms causes improved survival, motility, progressive motility of frozen-thawed sperm. Alteration of fatty acid composition of sperm, especially DHA due to dietary PUFA variation is presented in Table 4. It is noteworthy that dietary n-3 PUFA must be fed during the early stages of spermatogenesis for it to be incorporated into sperm lipids [16].

In contrast to above results, Fair et al [78] observed that dietary supplementation with fish oil at $2 \%$ of the total diet in rams successfully modified the plasma n-6:n-3 ratio, but had limited effects on the corresponding sperm fatty acid profile. Although dietary supplementation with fish oil increased semen concentration it had no effect on the quality of liquid stored semen. This is in agreement with De Graaf et al [96], who reported that rams supplemented with $5 \%$ of sunflower oil, high in LA, did not im- prove the cryosurvival of ram spermatozoa.

According to Gholami et al [104], heat stress has detrimentally decreased sperm quality parameters in Holstein bulls and the dietary omega-3 supplementation or its precursors, improved in vitro quality and motility parameters of fresh semen. However, this effect was not obvious in frozen-thawed semen. PUFA are associated with increased oxidative stress, which can reduce semen quality [7]; therefore, several mechanisms need to be considered when examining the overall effects of n-3 PUFA. In goats, Dolatpanah et al [53] implemented the study of evaluating the effects of dietary supplementation with fish oil $(2.5 \% \mathrm{DM})$ and vitamin $\mathrm{E}(0.3 \mathrm{~g} / \mathrm{kg} \mathrm{DM})$ on semen quality, results from this study showed that fish oil supplement to diet could improve the quality and quantity of goat semen and also emphasized the importance of adequate dietary vitamin $\mathrm{E}$ in preventing peroxidative reactions. The purpose of vitamin E supplementation was to prevent any

Table 4. Effect of polyunsaturated fatty acids on alteration of fatty acid composition of sperm lipid

\begin{tabular}{|c|c|c|c|c|c|c|c|}
\hline \multirow{2}{*}{ Reference } & \multirow{2}{*}{ Species } & \multirow{2}{*}{ Item } & \multicolumn{5}{|c|}{ PUFA (g/100 g FA) } \\
\hline & & & PUFA & DHA & $n-3$ & $n-6$ & $n-6 / n-3$ \\
\hline \multirow[t]{8}{*}{ Samadian et al [16] } & Ram & $\mathrm{CO}$ & 34.07 & 0.00 & 11.63 & 22.32 & 1.92 \\
\hline & & Fresh sperm & & & & & \\
\hline & & - 1st week & 33.27 & $22.91^{\mathrm{a}}$ & 23.60 & 8.00 & 0.34 \\
\hline & & -13th week & 32.64 & $25.10^{\mathrm{a}}$ & 25.83 & 6.72 & 0.26 \\
\hline & & FO & 20.33 & 2.94 & 10.37 & 9.95 & 0.96 \\
\hline & & Fresh sperm & & & & & \\
\hline & & -1st week & 31.72 & $23.60^{\mathrm{a}}$ & 23.99 & 9.59 & 0.40 \\
\hline & & -13th week & 39.04 & $31.09^{b}$ & 31.67 & 7.28 & 0.23 \\
\hline \multirow[t]{8}{*}{ Jafaroghli et al [17] } & Ram & $\mathrm{CO}$ & 25.28 & 0.50 & 9.30 & 15.58 & 1.67 \\
\hline & & Fresh sperm & & & & & \\
\hline & & - 1st week & 32.06 & $22.11^{\mathrm{a}}$ & 22.67 & 9.39 & 0.42 \\
\hline & & -12th week & 32.38 & $23.76^{a}$ & 24.39 & 7.99 & 0.33 \\
\hline & & FO & 21.63 & 0.65 & 11.12 & 10.51 & 0.96 \\
\hline & & Fresh sperm & & & & & \\
\hline & & -1st week & 32.12 & $22.22^{\mathrm{a}}$ & 22.36 & 9.90 & 0.44 \\
\hline & & -12th week & 39.26 & $30.54^{b}$ & 31.21 & 8.05 & 0.25 \\
\hline \multirow[t]{9}{*}{ Khoshvaght et al [14] } & Bull & Diet & & & & & \\
\hline & & $\mathrm{CO}$ & 17.22 & 0.00 & 1.53 & 15.69 & 11.25 \\
\hline & & FO & 40.16 & 2.94 & 11.85 & 28.31 & 2.39 \\
\hline & & Fresh sperm & & & & & \\
\hline & & $\mathrm{CO}$ & 28.68 & 19.30 & 19.80 & 7.99 & 0.42 \\
\hline & & FO & $40.81 * *$ & $29.92^{* *}$ & $30.74^{* *}$ & 8.39 & $0.27^{* *}$ \\
\hline & & Frozen sperm & & & & & \\
\hline & & $\mathrm{CO}$ & 19.43 & 3.79 & 5.51 & 13.85 & 2.51 \\
\hline & & FO & 24.23 & $12.40^{*}$ & $16.29^{*}$ & 7.61 & $0.47^{*}$ \\
\hline \multirow[t]{8}{*}{ Moallem et al [13] } & Bull & Diet & & & & & \\
\hline & & $\mathrm{CO}$ & 23.72 & 0.04 & 2.30 & 20.14 & 8.76 \\
\hline & & FLO & 36.18 & 0.00 & 11.62 & 23.41 & 2.01 \\
\hline & & FO & 27.63 & 1.28 & 5.45 & 21.65 & 3.96 \\
\hline & & Fresh sperm & & & & & \\
\hline & & $\mathrm{CO}$ & 45.10 & $21.54^{c}$ & $22.18^{c}$ & $22.44^{\mathrm{a}}$ & $1.01^{\mathrm{a}}$ \\
\hline & & FLO & 45.79 & $26.44^{b}$ & $27.39^{b}$ & $18.08^{b}$ & $0.66^{b}$ \\
\hline & & FO & 45.62 & $29.32^{\mathrm{a}}$ & $30.09^{\mathrm{a}}$ & $15.06^{c}$ & $0.50^{c}$ \\
\hline
\end{tabular}

PUFA, polyunsaturated fatty acids; FA, fatty acids; DHA, docosahexaenoic acid; CO, control diet; FO, fish oil; FLO, flaxseed oil.

$a, b, c$ Within columns, means with different letter superscripts are statistically different $(p<0.05)$.

${ }^{*} p<0.05 ;{ }^{* *} p<0.01$. 
peroxidation of the PUFA, which could potentially reduce the level of the DHA in the sperm phospholipids, and decreased production of free radicals which damage animal tissues [105]. Similar results were found in rams by Alizadeh et al [97]. Also, Jafaroghli et al [17] observed that rams fed fish oil at level of 2.5\% DM accompanied with $300 \mathrm{mg}$ of vitamin C/kg DM had a significant increase of the proportion of DHA in spermatozoa, motility, HOS and percentage of sperm with normal acrosome, which may have beneficial effects on fertility.

It has been known that PUFA and cholesterol are the main targets for free radical (ROS) damage, and an inverse relationship between lipid peroxides and sperm motility has been clearly demonstrated [106]. Spermatozoa membrane of bulls and rams contains high PUFA resulting in more susceptible to ROS that leads to declined sperm mobility, viability and sperm-oocyte fusion due to a reduction in axonemal protein phosphorylation [107]. Interstingly, ROS induces capacitation and acrosome reaction of sperm $[108,109]$ but excessive ROS is detrimental to sperm motility [110] due to hydroxyl radical formation which causes oxidation of sperm membrane lipids and thiol proteins [111]. Therefore, dietary supplementation with antioxidants such as vitamin $\mathrm{E}, \mathrm{C}$ contributes to making a balance between the production of ROS and the antioxidant capacity against damage caused by free radicals to PUFA of sperm plasma membrane.

In the light of recent sperm proteomic studies, it has been found that there is a relationship between antioxidant related proteins and sperm motility and fertility $[112,113]$, which may be associated with PUFA. These proteins, which includes glutathione peroxidase (GPx), glutathione S-transferases, superoxide dismutase (SOD) and catalase, are main antioxidant enzymes in mammalian cells. There was a tendency for a correlation between SOD activity in seminal plasma and DHA content in sperm [102, 114], while GPx was in tendency associated with LA [102]. A decrease in PUFA content was related to decreased antioxidant levels (GPx and SOD) in seminal plasma of aging bulls during reproductive period [6]. Recently, a lot of protein markers have been identified in mammal sperm and some have association with capacitated sperm and fertility. Park et al [115] identified a set of fertility-related proteins in bull spermatozoa, among found protein markers, enolase 1 (ENO1), voltage dependent anion channel 2 (VDAC2) and ubiquinol-cytochrome-c reductase complex core protein 2 (UQCRC2) were significantly correlated with individual fertility. It is important to note that UQCRC2, subunits of the respiratory chain protein ubiquinol cytochrome $\mathrm{c}$ reductase, are associated with oxidative stress and the generation of ROS in mitochondria [116,117], UQCRC2 deficiency induces ROS production [118]. Additionally, Manjunath and Therien [119] found that the BSP proteins, which bind to sperm plasma membrane phospholipids specifically phosphatidylcholine, phophatidylcholine plasmalogen and sphingomyelin, stimulated cholesterol and phospholipid efflux from the sperm membrane. Thus, it is possible that there is a close relationship between BSP proteins and sperm membrane PUFA in regulating sperm capacitation. A recent study reported that ubiquinol cytochrome $\mathrm{c}$ reductase regulates tyrosine phosphorylation during capacitation and the acrosome reaction in boar spermatozoa [112]. However, the mechanism of interaction between some protein makers found and PUFA in regulating oxidative stress and capacitation of sperm has been yet elucidated and need further studies.

From the above discussion, it is clear that dietary PUFA supplementation have significant effects on the testis development as well as on the quality of fresh semen and sperm and post-thawed sperm. There have been, however, several conflicting results, which may be due to difference in dietary sources of fat, n-3:n-6 PUFA ratio and various characteristics of fatty acid composition of semen and sperm in ruminant species.

\section{STRATEGIES FOR USING POLYUNSATURATED FATTY ACIDS IN ENHANCING REPRODUCTION PERFORMANCE OF MALE RUMINANTS}

The $n-3$ and n- 6 PUFA cannot be synthesized by vertebrates and therefore must be provided through the diet, either in the form of 18-carbon plant precursors (linolenic acid or LA) or derivatives of 20 to 22 carbons found in animal tissues. The transfer of dietary PUFA to sperm has been shown to be effective in ruminants species $[13,19]$. The diet of ruminants typically contains $4 \%$ to $5 \%$ fat. Higher levels may adversely affect rumen microbial fermentation so the general recommendation is that total dietary fat should not exceed $6 \%$ to $7 \%$ of dietary DM $[120,121]$. Primary sources of lipid in the ruminant diet are forages and concentrates, although the lipid content can be increased by the use of fat supplements. Forages generally are low in total lipid, but a high proportion $(>50 \%)$ of the fatty acids in forages are n-3 PUFA. Because forage constitutes a large part of the diet of grazing ruminants, fresh forages often are the major dietary source of n-3 PUFA. Depending on the species of grass, the fatty acids composition varies with $55 \%$ to $70 \%$ as n-3 PUFA and $10 \%$ to $20 \%$ as n-6 PUFA. Cattle fed grass would have received a high proportion of the PUFA as n-3 PUFA while the short term grainfed and long term grain-fed groups would have a high proportion of n-6 PUFA in their diets [122]. However, dry matter of green fodder is low, which leads to total amount of PUFA in ruminant ration is not much as well. Among the different fatty acid sources, which are rich in PUFA, plant-derived oils such as sunflower, safflower, linseed and soybeans are of considerably significance in improving reproductive performance due to their high content of essential fatty acids. Vegetable oil have high PUFA content, especially n-3 PUFA is linseed oil (Table 5). Fish oil is also considered as an ideal source of n-3 PUFA (high in EPA 20:5 n-3 and DHA 22:6 n-3) in ruminant diets due to a portion of the n-3 fatty acids of fish oil escapes biohydrogenation in the rumen [123]. 
A major challenge in increasing the PUFA content of ruminant tissues differ considerably from those of non-ruminants as the ruminal microorganisms are able to transform unsaturated fatty acids in a process called biohydrogenation, in which hydrogen addition via microbial enzymes removes double bonds in a fatty acyl chain converting PUFA to saturated FAs. Microbial biohydrogenation of n-3 and n-6 PUFA by an anaerobic rumen bacterium Butyrivibrio fibrisolvens is highly dependent on rumen $\mathrm{pH}$. Depending on conditions in the rumen, various proportions of stearic acid and trans intermediates are produced from LA [35]. This biohydrogenation can leads to the loss of PUFA amount in diets. Therefore, there has been considerable interest during the past years in finding ways to protect dietary unsaturated fatty acids from biohydrogenation (rumen bypass fat). These methods include formaldehyde treatment of a lipid-protein matrix [124], microencapsulation with a water insoluble lipid coating [125], preparation of fatty acid amides [126], and formation of Ca salts of fatty acids [127]. Of these calcium salts has been known the best effectiveness. Nowadays, a lot of its commercial products have been produced and used for livestock around the world. The mechanism whereby Ca-salts provide "protection" from rumen digestion is related to the inertness of the Ca-fatty acid complex in the typical rumen environment. Calcium salts of long chain fatty acids (Ca-LCFA) are insoluble soaps produced by reaction of carboxyl group of LCFA and calcium salts $\left(\mathrm{Ca}^{++}\right)$. Degree of insolubility of the Ca soaps depends upon the rumen $\mathrm{pH}$ and type of fatty acids. When rumen $\mathrm{pH}$ is more than 5.5 , Ca-LCFA is inert in rumen. As dissociation constant (pKa) of Ca-LCFA is 4 to 5 , dissociation is significant, when $\mathrm{pH}$ decreases to 6.0. In acidic $\mathrm{pH}$ of the abomasum, fatty acids is dissociated from Ca-LCFA and then absorbed efficiently from small intestine. Therefore, factors such as low rumen $\mathrm{pH}$ and increased unsaturation of the fatty acid can lead to dissociation of the Ca-fatty acid complex allowing biohydrogenation to occur [34]. The dissociation of calcium soaps of long-chain fatty acids in rumen fluid was maximum at $\mathrm{pH} 5.0$, minimum at $\mathrm{pH} 6.5$, and dependent on unsaturation of fatty acids in the soaps. Soluble calcium in the acetate-buffered rumen fluid was higher than predicted from pKa of calcium soaps, due to formation of soluble calcium acetate; nevertheless, the relative patterns were similar to their pKa values [128]. Among all forms of bypass fat, Ca-LCFA is relatively less degradable in rumen, has highest intestinal digestibility and serve as an additional source of calcium [129].

In adition to the sources and types of PUFA supplements, the quantity and ratio of n-6/n-3 PUFA is necessary to have proper concern. It is thought that both man and livestock species evolved on a diet with an n-6 to n-3 PUFA ratio of 1:1, but modern dietary trends have increased this ratio. For example, in westernized human populations this ratio now ranges from 10:1 to 25:1 [130]. Many researchs conducted to evaluate effects of PUFA on reproductive performance in ruminant species such as in ram [70,78]; buffalo [98], bovine [13] and obtained expected results. However, there is little information about the effect of optimum n-6/n-3 ratios on male ruminants. Am-in et al [131] pointed out that the ratios of n-6/n-3 PUFA in boar sperm were negatively correlated with sperm motility, viability, normal morphology, and normal plasma membranes, which suggested that the appropriate ratio of n-6/n-3 PUFA in males is important for sperm quality. It is supported by Liu et al [132], who demonstrated the optimum ratio in boars was 6.6. Similarly, Yan et al [133] revealed that a balanced $n-6 / n-3$ ratio was important in male rat reproduction and the optimum ratio of $n-6 / n-3$ PUFA in rat diets was 0.66 in comparison with four others $(7.69,2.50,1.18$, and 0.35 respectively). In spite of having less data in order to demonstrate this optimum ratio in male ruminant reproduction, several studies showed the ratio of $n-6 / n-3$ PUFA which had positive impact on improving the quality of ram sperm was $0.96[16,17]$ and that of bull sperm was 2.01 [13] and 2.39 [14]. It is interesting thing in the finding of Moallem et al [13] is that the ratio of 2.01 had better influence on the sperm quality in comparison with the ratio of 3.96 [13]. Thus, it is really necessary to implement further researches for elucidating the issue in male ruminants.

The dietary supplementation with PUFA can be an optimum option for improving reproductive performance of male ruminants. However, another way is direct supplementation of PUFA in semen extender. The most thing is here that the combination

Table 5. Fatty acid composition of dietary fat sources (Thatcher and Staples [2])

\begin{tabular}{|c|c|c|c|c|c|c|c|}
\hline \multirow[b]{2}{*}{ Source of fat } & \multicolumn{7}{|c|}{ Fatty acid (g/100 g) } \\
\hline & $\begin{array}{c}\text { Myristic } \\
\text { C14:0 }\end{array}$ & $\begin{array}{c}\text { Palmitic } \\
\text { C16:0 }\end{array}$ & $\begin{array}{c}\text { Palmitoleic } \\
\text { C16:1 }\end{array}$ & $\begin{array}{c}\text { Stearic } \\
\text { C18:0 }\end{array}$ & $\begin{array}{l}\text { Oleic } \\
\text { C18:1 }\end{array}$ & $\begin{array}{c}\text { Linoleic } \\
\text { C18:2 }\end{array}$ & $\begin{array}{c}\text { Linolenic } \\
\text { C18:3 }\end{array}$ \\
\hline Soya bean oil & $<1$ & 11 & $<1$ & 4 & 23 & 54 & 8 \\
\hline Rice bran oil & $<1$ & 21 & $<1$ & 3 & 45 & 36 & $<1$ \\
\hline Mustard oil & $<1$ & 3 & $<1$ & $<1$ & 17 & 15 & 13 \\
\hline Linseed oil & $<1$ & 5 & 1 & 3 & 20 & 16 & 55 \\
\hline Safflower oil & $<1$ & 7 & $<1$ & 2 & 12 & 78 & $<1$ \\
\hline Sunflower oil & $<1$ & 7 & $<1$ & 5 & 19 & 68 & 1 \\
\hline Cottonseed oil & 1 & 23 & $<1$ & 3 & 18 & 54 & 1 \\
\hline Canola oil & $<1$ & 4 & $<1$ & 2 & 63 & 19 & 9 \\
\hline Rapeseed oil & $<1$ & 5 & $<1$ & 2 & 54 & 22 & 11 \\
\hline
\end{tabular}


of vitamin $\mathrm{E}$ or vitamin $\mathrm{C}$ as antioxidants along with PUFA is very crucial in practice to protect damage of sperm membrane from attack of ROS. Moreover, doses of PUFA and vitamin E added in semen extender is needed to adjust to an accurate level. For example, this ratio in bull is $10 \mathrm{ng} / \mathrm{mL}$ of $\mathrm{n}-3$ PUFA and 0.4 $\mathrm{mM}$ of vitamin $\mathrm{E}$ [19], while in ram is $10 \mathrm{ng} / \mathrm{mL}$ of $\mathrm{n}-3$ PUFA and $0.2 \mathrm{mM}$ of vitamin $\mathrm{E}$ [89].

\section{DIFFERENCE OF USING POLYUNSATURATED FATTY ACIDS IN MALE NON-RUMINANT AND RUMINANT REPRODUCTION}

The male non-ruminants, similar to male ruminants, require certain essential fatty acids such as n-3 and n- 6 PUFA that must be supplied in diet because they do not have an enzyme system capable of synthesizing these fatty acids in the body. Various experiments carried out in boars [92,132], chicken [69], quails [136], rabbit [25] and rat [133] indicated that PUFA have the same role and effect on male reproductive performace as in male ruminants (Table 6). In general, dietary supplementation with PUFA in male non-ruminants, with proper quantity and $n-6 / n-3$ PUFA ratio according as every species, can lead to modification of fatty acid profile of sperm, improvement of the semen quality and reproductive performance. Also, incorporation of antioxi- dants such as vitamin $\mathrm{E}$ in diets can contribute to better antioxidant status of semen, resulting in improved sperm quality. Several conflicting results are mainly due to large variation in type and quantity of dietary fats, especially n-3 and n-6 PUFA as well as different species.

Doing the comparison between ruminants and non-ruminants, major difference is due to conversion of dietary PUFA to cell tissues. It is well known that lipid digestion is different in nonruminant and ruminant, which has an important effect on the transfer of fatty acids from the diet into the cell tissues. The principal site of digestion of dietary lipids in non-ruminants is small intestine where pancreatic lipase breaks the triacylglycerols down to mainly 2-monoacylglycerols and free fatty acids and absorbed mediated by lipoprotein lipase enzyme after the micelle formation, which is widely distributed throughout the body. Therefore, dietary fatty acids in the non-ruminant are absorbed unchanged before incorporation into the tissue lipids [137]. It is clear that the supply of unsaturated fatty acids such as PUFA to cell tissues in non-ruminants may be simply increased by increasing their proportion in the diet. In addition, non-ruminant diets are high in concentrate feed and low in green fodder, which results in higher proportion of $n-6$ PUFA as compared to n-3 PUFA, thus it is necessary for adding n-3 PUFA in diet to balance the ratio of n-6/n-3 PUFA according as every species.

Table 6. Effect of PUFA on reproduction performance in non-ruminants

\begin{tabular}{|c|c|c|c|c|c|}
\hline Species & Fat source & Percent inclusion & $n-6 / n-3$ & Findings & References \\
\hline \multirow[t]{6}{*}{ Boars } & SO & $60 \mathrm{~g} / \mathrm{d}$ & 14.4 & \multirow{4}{*}{$\begin{array}{l}\text { PUFA in diets can modify the FA profile of sperm and n-6/n-3 PUFA } \\
\text { (6.6) contributes to a much better antioxidant status and improved } \\
\text { progressive sperm motility. } \\
\text { Supplementation with } 400 \mathrm{mg} / \mathrm{kg} \text { vitamin E contributes to a better } \\
\text { antioxidant status in boars, resulting in improved sperm motility. }\end{array}$} & \multirow[t]{4}{*}{ Liu et al [132] } \\
\hline & SO and FO & $45+15 \mathrm{~g} / \mathrm{d}$ & 6.6 & & \\
\hline & SO and FO & $45+60 \mathrm{~g} / \mathrm{d}$ & 2.2 & & \\
\hline & Vit.E & $200 \mathrm{mg}$ or $400 \mathrm{mg} / \mathrm{kg}$ of feed & & & \\
\hline & MO & $60 \mathrm{~g} / \mathrm{d}$ & 0.09 & \multirow[t]{2}{*}{ Fish oils did not influence fresh semen production or quality } & \multirow[t]{2}{*}{ Castellano et al [92] } \\
\hline & TO & $60 \mathrm{~g} / \mathrm{d}$ & 0.05 & & \\
\hline & AO & & 10.0 & \multirow{3}{*}{$\begin{array}{l}\text { The age related decrease in the number of spermatozoa is almost } \\
\text { completely prevented by feeding the birds with the oils enriched in } \\
\text { either EPA, C20:4n-6 or DHA, C22:6n-3. }\end{array}$} & \multirow{3}{*}{ Surai et al [69] } \\
\hline & TO & $200 \mathrm{mg} / \mathrm{kg}$ of feed & 0.6 & & \\
\hline & Vit. E & & & & \\
\hline \multirow[t]{3}{*}{ Japanese quails } & SFO & $3 \%(w / w)$ of feed & 251.2 & \multirow{3}{*}{$\begin{array}{l}\text { FO and FLO diets can be used as efficient tool for improving repro- } \\
\text { ductive performance of Japanese quail males }\end{array}$} & \multirow[t]{3}{*}{ Hazim et al [134] } \\
\hline & $\mathrm{CO}$ & & 60.1 & & \\
\hline & FLO & & 12.8 & & \\
\hline \multirow[t]{2}{*}{ Stallion } & FLO & $60 \mathrm{~g} / \mathrm{d}$ & 0.60 & \multirow{2}{*}{$\begin{array}{l}\text { No improvements were found in motility, membrane-intact sperma- } \\
\text { tozoa, morphologically normal spermatozoa regardless source of } \\
\text { supplementation. }\end{array}$} & \multirow[t]{2}{*}{ Grady et al [135] } \\
\hline & FO & $150 \mathrm{~g} / \mathrm{d}$ & 0.57 & & \\
\hline \multirow[t]{5}{*}{ Rat } & so & $100: 0$ & 7.69 & \multirow{5}{*}{$\begin{array}{l}\text { Improvement of testis development, density and motility of sperm, } \\
\text { the } 0.66 \text { group were higher than other groups about all parameters } \\
\text { Serum reproductive hormone levels were significantly affected by the } \\
n-6 / n-3 \text { ratios }\end{array}$} & \multirow[t]{5}{*}{ Yan et al [133] } \\
\hline & SO:FLO & $75: 25$ & 2.50 & & \\
\hline & SO:FLO & $50: 50$ & 1.18 & & \\
\hline & SO:FLO & $25: 75$ & 0.66 & & \\
\hline & SO:FLO & $0: 100$ & 0.35 & & \\
\hline
\end{tabular}

PUFA, polyunsaturated fatty acids; SO, soybean oil; FO, fish oil; MO, menhaden oil; TO, tuna oil; MaO, maize oil; AO, arasco oil; SFO, sunflower oil; CO, corn oil; FLO, flaxseed oil; rich in n-3 PUFA. 


\section{CONCLUSION}

PUFA are critical nutrients which play an important role in maintaining the physical properties of the sperm membrane fluidity. Dietary supplementation with PUFA can alter fluidity/ permeability of sperm membrane and enhance reproductive performance in male ruminants thought improving testis development, spermatogenesis, motility and viability of sperm before and post freezing. Combination of PUFA and vitamin E, C in diets and semen extender at level of proper amount according to each species may bring better effect on improvement of sperm quality thanks to their capacity of antioxidant and protection of sperm membrane integrity. The use of PUFA in ruminant ration is very useful; however, biohydrogenation occurring in rumen can cause loss of intact PUFA in the diet due to alteration from unsaturated fatty acids to saturated fatty acids. In this case, use of protected fat or bypass fat is an optimum way of protecting PUFA integrity.

PUFA are associated with activity of hormones such as $\mathrm{LH}$, FSH, testosterone, PGF2 $\alpha$, IGF-1. Fluctuation of these hormone concentration can affect reproductive health in male animals through biological mechanisms.

It is necessary to conduct further researchs to make clear about the effect of optimum n-6/n-3 ratio on various male ruminants, thereby contribute to modifying their diets in practice and achieve maximum effect on reproduction.

\section{CONFLICT OF INTEREST}

We certify that there is no conflict of interest with any financial organization regarding the material discussed in the manuscript.

\section{ACKNOWLEDGMENTS}

We are grateful to ICAR-National Dairy Research Institute, Karnal, Haryana, India for providing us with the necessary support.

\section{REFERENCES}

1. Santos JE, Bilby TR, Thatcher WW, Staples CR, Silvestre FT. Long chain fatty acids of diet as factors influencing reproduction in cattle. Reprod Domest Anim 2008;43:23-30.

2. Thatcher WW, Staples RC. Using fats and fatty acids to enhance reproductive performance. Proceedings of the 5th Mid-Atlantic Nutrition Conference. Timonium, MD: University of Maryland; 2007. p. 116-29.

3. Poulos A, White IG. The phospholipid composition of human spermatozoa and seminal plasma. J Reprod Fertil 1973;35:265-72.

4. Poulos A, Darin Bennett A, White IG. The phospholipid bound fatty acids and aldehydes of mammalian spermatozoa. Comp Biochem Physiol B 1973;46:541-9.

5. Jain YC, Anand SR. Fatty acids and fatty aldehydes of buffalo seminal plasma and sperm lipid. J Reprod Fertil 1976;47:261-7.
6. Kelso KA, Redpath A, Noble RC, Speake BK. Lipid and antioxidant changes in spermatozoa and seminal plasma throughout the reproductive period of bulls. J Reprod Fertil 1997;109:1-6.

7. Wathes DC, Abayasekara DRE, Aitken RJ. Polyunsaturated fatty acids in male and female reproduction. Biol Reprod 2007;77:190-201.

8. Wassall SR, Stillwell W. Polyunsaturated fatty acid-cholesterol interactions: domain formation in membranes. Biochim Biophys Acta 2009;1788:24-32.

9. Stubbs CD, Smith AD. The modification of mammalian membrane polyunsaturated fatty acid composition in relation to membrane fluidity and function. Biochim Biophys Acta 1984;779:89-137.

10. Hammerstedt RH, Graham JK, Nolan JP. Cryopreservation of mammalian sperm: what we ask them to survive. J Androl 1990;11:73-88.

11. Robinson JJ, Ashworth CJ, Rooke JA, Mitchell LM, McEvoy TG. Nutrition and fertility in ruminant livestock. Anim Feed Sci Technol 2006; 126:259-76.

12. Rooke JA, Shao CC, Speake BK. Effects of feeding tuna oil on the lipid composition of pig spermatozoa and in vitro characteristics of semen. Reproduction 2001;121:315-22.

13. Moallem U, Neta N, Zeron Y, Zachut M, Roth Z. Dietary a-linolenic acid from flaxseed oil or eicosapentaenoic and docosahexaenoic acids from fish oil differentially alter fatty acid composition and characteristics of fresh and frozen-thawed bull semen. Theriogenology 2015;83:1110-20.

14. Khoshvaght A, Towhidi A, Zare-shahneh A, et al. Dietary n-3 PUFA improve fresh and post-thaw semen quality in Holstein bulls via alteration of sperm fatty acid composition. Theriogenology 2016;85: 807-12.

15. Adibromadi M, Najafi MH, Zeinoaldini S, Ganjkhanlou M, Yousefi AR. Effect of dietary soybean oil and fish oil supplementation on blood metabolites and testis development of male growing kids. Egypt J Sheep Goat Sci 2012;7:19-25.

16. Samadian F, Towhidi A, Rezayazdi K, Bahreini M. Effects of dietary $\mathrm{n}-3$ fatty acids on characteristics and lipid composition of ovine sperm. Animal 2010;4:2017-22.

17. Jafaroghli M, Abdi-Benemar H, Zamiri MJ, Khalili B, Farshad A, Shadparvar AA. Effects of dietary n-3 fatty acids and vitamin C on semen characteristics, lipid composition of sperm and blood metabolites in fat-tailed Moghani rams. Anim Reprod Sci 2014;147:17-24.

18. Kiernan, M, Fahey AG, Fair S. The effect of the in vitro supplementation of exogenous long-chain fatty acids on bovine sperm cell function. Reprod Fertil Dev 2013;25:947-54.

19. Towhidi A, Parks JE. Effect of n-3 fatty acids and $\alpha$-tocopherol on post-thaw parameters and fatty acid composition of bovine sperm. J Assist Reprod Genet 2012;29:1051-6.

20. Abavisani A, Arshami J, Naserian AA, Kandelousi MAS, Azizzadeh M. Quality of bovine chilled or frozen-thawed semen after addition of omega-3 fatty acids supplementation to extender. Int J Fertil Steril 2013;7:161-8.

21. Swain JE, Miller Jr RR. A postcryogenic comparison of membrane fatty acids of elephant spermatozoa. Zoo Biol 2000;19:461-73.

22. Waterhouse KE, Hofmo PO, Tverdal A, Miller Jr RR. Within and 
between breed differences in freezing tolerance and plasma membrane fatty acid composition of boar sperm. Reproduction 2006;131:887-94.

23. White IG. Lipids and calcium uptake of sperm in relation to cold shock and preservation: A review. Reprod Fertil Dev 1993;5:639-58.

24. Neuringer M, Anderson GJ, Connor WE. The essentiality of n-3 fatty acids for the development and function of the retina and brain. Ann Rev Nutr 1988;8:517-41.

25. Castellini C, Lattaioli P, Dal bosco A, Minelli A, Mugnai C. Oxidative Status and semen characteristics of rabbit buck as affected by dietary Vitamin E, C and n-3 fatty acids. Reprod Nutr Dev 2003;43:91-103.

26. Harfoot CG. Lipid metabolism in the rumen. Prog Lipid Res 1978;17: 21-54.

27. Palmquist DL, Jenkins TC. Fat in lactation rations: Review. J. Dairy Sci 1980;63:1-14.

28. Davis CL. Fats in animal feeds. Sycamore, IL: Barnaby Inc.; 1990.

29. Harfoot CG, Hazlewood GP. Lipid metabolism in the rumen. In: Hobson PN, editor. The rumen microbial ecosystem. NY, USA: Elsevier Appl. Sci. Publ. Co., Inc.; 1988. p. 285.

30. Henderson C. The effects of fatty acids on pure cultures of rumen bacteria. J Agric Sci 1973;81:107-12.

31. Garton GA, Lough AK, Vioque E. Glyceride hydrolysis and glycerol fermentation by sheep rumen contents. J Gen Microbiol 1961;25: 215-25.

32. Beam TM, Jenkins TC, Moate PJ, Kohn RA, Palmquist DL. Effects of amount and source of fat on the rates of lipolysis and biohydrogenation of fatty acids in ruminal contents. J Dairy Sci 2000;83: 2564-73.

33. Van Nevel CJ, Demeyer DI. Lipolysis and biohydrogenation of soybean oil in the rumen in vitro: Inhibition by antimicrobials. J Dairy Sci 1995;78:2797-806.

34. Demeyer D, Doreau M. Targets and procedures for altering ruminant meat and milk lipids. Proc Nutr Soc 1999;58:593-607.

35. Harfoot CG, Hazlewood GP. Lipid metabolism in the rumen. In: Hobson PN, Stewart CS, editors. The rumen microbial ecosystem. London, UK: Chapman \& Hall; 1997. p. 382-426.

36. Harfoot CG, Noble RC, Moore JH. Factors influencing the extent of biohydrogenation of linoleic acid by rumen microorganisms in vitro. J Sci Food Agric 1973;24:961-70.

37. Doreau M, Ferlay A. Digestion and utilisation of fatty acids by ruminants. Anim Feed Sci Technol 1994;45:379-96.

38. Noble RC. Lipid metabolism in the chick embryo: Some recent ideas. J Exp Zool 1987;1:65-73.

39. Christie WWW. Gas chromatography; a practical guide. 1st edn, Ayr, Scotland: The Oily Press; 1989.

40. Yeagle P. The lipids of cell membranes. In: The membranes of cells. London, UK: Academic Press; 1987. p. 22-39.

41. Jones R, Mann T. Damage to ram spermatozoa by peroxidation of endogenous phospholipids. J Reprod Fertil 1977;50:261-8.

42. Alvarez JG, Storey BT. Spontaneous lipid peroxidation in rabbit epididymal spermatozoa: its effect on sperm motility. Biol Reprod 1982;27: 1102-08.

43. McDonald P, Edwards RA, Greenhalgh JFD. Animal Nutrition. 4th edn. London, UK: Longman Ltd.; 1988. 34-45.

44. Alberts B, Bray D, Lewis J, et al. The molecular organisation of cells: The plasma membrane; the lipid bilayer. In: Molecular biology of the cell. New York: Garland Publishing Incorporated; 1983. p. 256-64.

45. Komarek RJ, Pickett BW, Gibson EW, Lanz RN. Composition of lipids in stallion semen. J Reprod Fertil 1965;10:337-42.

46. Scott TW. Lipid metabolism of spermatozoa. J Reprod Fertil 1973;18: 65-76.

47. Poulos A, Brown-Woodman PDC, White IG, Cox RI. Changes in phospholipids of ram spermatozoa during migration through the epididymis and possible origin of prostaglandin F2 $\alpha$ in testicular and epididymal fluid. Biochim Biophys Acta 1975;388:12-8.

48. Rana APS, Majumder GC, Misra S, Ghosh A. Lipid changes of goat sperm plasma membrane during epididymal maturation. Biochim Biophys Acta 1991;1061:185-96.

49. Lenzi A, Picardo M, Gandini L, Dondero F. Lipids of the sperm plasma membrane: from polyunsaturated fatty acids considered as markers of sperm function to possible scavenger therapy. Hum Reprod 1996;2: 246-56.

50. Scott TW, Dawson RM. Metabolism of phospholipids by spermatozoa and seminal plasma. Biochem J 1968;108:457-75.

51. Hartree EF, Mann T. Phospholipids in ram semen: metabolism of plasmalogen and fatty acids. Biochem J 1961;80:464-76.

52. Lardy HA, Phillips PH. The interrelation of oxidative and glycolytic processes as sources of energy for bull spermatozoa. Am J Physiol 1994;133:602-9.

53. Dolatpanah MB, Towhidi A, Farshad A, Rashidi A, Rezayazdi A. Effects of dietary fish oil on semen quality of goats. Asian-Australas J Anim Sci 2008;21:29-34.

54. Cross NL. Decrease in order of human sperm lipids during capacitation. Biol Reprod 2003;69:529-34.

55. Kadirvel G, Kumar S, Kumaresan A, Kathiravan P. Capacitation status of fresh and frozen-thawed buffalo spermatozoa in relation to cholesterol level, membrane fluidity and intracellular calcium. Anim Reprod Sci 2009;116:244-53.

56. Manna PR, Dyson MT, Stocco DM. Regulation of the steroidogenic acute regulatory protein gene expression: present and future perspectives. Mol Hum Reprod 2009;15:321-33.

57. Georgiadi A, Kersten S. Mechanisms of gene regulation by fatty acids. Adv Nutr 2012;3:127-34.

58. Watanabe K. Prostaglandin F synthase. Prostaglandins Other Lipid Mediat 2002;401-07.

59. Lands WE. Biochemistry and physiology of n-3 fatty acids. FASEB J 1992;6:2530-6.

60. Mekonnen G, Boland M, Gordon I. The effect of prostaglandin on semen production and libido in the ram. Ir Vet J 1989;42:56-9.

61. Shankar U, Benjamin BR, Agarwal SK. Effect of prostaglandin F2a (PGF2 $\alpha$ ) on reaction time and semen characteristics of buffalo bulls. Ind J Anim Sci 1984;54:38-40.

62. Titiroongruang J, Hirunpattarawong P, Sophonpattana P, Singlor J, Tummaruk P. Effects of prostaglandin F2a on serum testosterone and semen output in Holstein Friesian bulls in tropical climate. Thai 
J Vet Med Suppl 2011;41:159-60.

63. Olfati A, Moghaddam GH, Daghigh Kia H, Karami Shabankareh $H$. Effects of prostaglandin F2a treatment on semen characteristics of crossbred rams in the non-breeding season. J Cell Anim Biol 2013;7: 16-20.

64. Gustafsson BK, Graham EF, Crabo BG, Pavelko MK, Wagner WC. Pre-freeze supplementation of ram semen with PGE1 and PGF2 alpha: Effects on sperm vitality in vitro and on sperm transport in the ewe. In: Proceedings of the 10th Annual Meeting Society Study Reproduction; 1997. Abstract \# 10.

65. Ojeda S, Negro-Vilar A, McCann SM. Role of prostaglandins in the control of pituitary hormone secretion. Prog Clin Biol Res 1981;74: 229-47.

66. Jump DB, Clarke SD. Regulation of gene expression by dietary fat. Ann Rev Nutr 1999;19:63-90.

67. Saksena S, Hunt DM, Lau IF. Effects of prostaglandin F2 $\alpha$ on sperm count, sperm motility and fertilizing capacity in the male rabbit. Int J androl 1999;1:639-48.

68. Free MJ, Jaffe RA, Morford DE. Sperm transport through the rete testis in anesthetized rats: Role of the testicular capsule and effect of gonadotropins and prostaglandins. Biol Reprod 1980;22:1073-8.

69. Surai PF, Noble RC, Sparks NH, Speake BK. Effect of long-term supplementation with arachidonic or docosahexaenoic acids on sperm production in the broiler chicken. J Reprod Fertil 2000;120:257-64.

70. Esmaeili V, Shahverdi AH, Alizadeh AR, Alipour H, Chehrazi M. Saturated, omega- 6 and omega-3 dietary fatty acid effects on the characteristics of fresh, frozen-thawed semen and blood parameters in rams. Andrologia 2014;46:42-9.

71. Orth JM. Proliferation of Sertoli cells in fetal and postnatal rats: a quantitative autoradiographic study. Anat Rec 1982;203:485-92.

72. Almiron I, Chemes H. Spermatogenic onset. II. FSH modulates mitotic activity of germ and Sertoli cells in immature rats. Int J Androl 1988; 11:235-46.

73. Huhtaniemi IT, Warren DW, Catt KJ. Functional maturation of rat testis Leydig cells. Ann NY Acad Sci 1984;438:283-303.

74. Chandolia RK, Honaramooz A, Bartlewski PM, Beard AP, Rawlings NC. Effects of treatment with LH releasing hormone before the early increase in LH secretion on endocrine and reproductive development in bull calves. J Reprod Fertil 1997;111:41-50.

75. Bagu ET, Madgwick S, Duggavathia R, et al. Effects of treatment with LH or FSH from 4 to 8 weeks of age on the attainment of puberty in bull calves. Theriogenology 2004;62:861-73.

76. Hoeflich A, Reichenbach HD, Schwartz J, et al. Insulin-like growth factors and IGF-binding proteins in bovine seminal plasma. Domest Anim Endocrinol 1999;17:39-51.

77. Selvaraju S, Reddy IJ, Nandi S, Rao SB, Ravindra JP. Influence of IGF-I on buffalo (Bubalus bubalis) spermatozoa motility, membrane integrity, lipid peroxidation and fructose uptake in vitro. Anim Reprod Sci 2009;113:60-70.

78. Fair S, Doyle DN, Diskin MG, Hennessy AA, Kenny DA. The effect of dietary $n-3$ polyunsaturated fatty acids supplementation of rams on semen quality and subsequent quality of liquid stored semen.
Theriogenology 2014;81:210-9.

79. Robinson RS, Pushpakumara PG, Cheng Z, et al. Effects of dietary polyunsaturated fatty acids on ovarian and uterine function in lactating dairy cows. Reproduction 2002;124:119-31.

80. Stratikopoulos E, Szabolcs M, Dragatsis I, Klinakis A, Efstratiadis A. The hormonal action of IGF1 in postnatal mouse growth. Proc Natl Acad Sci 2008;105:19378-83.

81. Griffeth RJ, Bianda V, Nef S. The emerging role of insulin-like growth factors in testis development and function. Basic Clin Androl 2014; 24:12.

82. Lejeune H, Chuzel F, Thomas T, et al. Paracrine regulation of Leydig cells. Ann Endocrinol (Paris) 1996;57:55-63.

83. Henricks DM, Kouba AJ, Lackey BR, Boone WR, Gray SL. Identification of insulin-like growth factor I in bovine seminal plasma and its receptor on spermatozoa: influence on sperm motility. Biol Reprod 1998;59:330-7.

84. Watson PE. Recent developments and concepts in the cryopreservation of spermatozoa and the assessment of their post-thawing function. Reprod Fertil Dev1995;7:871-91.

85. Mandal R, Badyakar D, Chakrabarty J. Role of membrane lipid fatty acids in sperm cryopreservation. Adv Androl 2014;Article ID 190542.

86. Kandelousi MAS, Arshami J, Naserian AA, Abavisan A. The effects of addition of omega-3, 6, 9 fatty acids on the quality of bovine chilled and frozen-thawed sperm. Open Vet J 2013;3:47-52.

87. Kaka A, Wahid H, Rosnina N, et al. Alpha-linolenic acid supplementation in tris extender can improve frozen-thawed bull semen quality. Anim Reprod Sci 2015;153:1-7.

88. Nasiri AH, Towhidi A, Zeinoaldini S. Combined effect of DHA and a- tocopherol supplementation during bull semen cryopreservation on sperm characteristics and fatty acid composition. Andrologia 2012; 44:550-5.

89. Towhidi A, Zeinoaldini S, Ardebili R, Davachi ND, Nasiri AH. Combined n-3 fatty acids and $\alpha$-tocopherol supplementation improved the ovine sperm cryosurvival. Iran J Biotechnol 2013;11:238-43.

90. Aitken RJ, Harkiss D, Buckingham DW. Analysis of lipid peroxidation mechanisms in human spermatozoa. Mol Reprod Dev 1993;35: 302-15.

91. Kothari S, Thompson A, Agarwal A, du Plessis SS. Free radicals: Their beneficial and detrimental effects on sperm function. Indian J Exp Biol 2010;48:425-35.

92. Castellano CA, Audet I, Bailey JL, Laforest JP, Matte JJ. Dietary omega-3 fatty acids (fish oils) have limited effects on boar semen stored at $17^{\circ} \mathrm{C}$ or cryopreserved. Theriogenology 2010;74:1482-90.

93. Strzezek J, Lapkiewicz S, Lecewicz M. A note on antioxidant capacity of boar seminal plasma. Anim Sci Pep Rep 1999;17:181-8.

94. Maldjian A, Pizzi F, Gliozzi T, et al. Changes in sperm quality and lipid composition during cryopreservation of boar semen. Theriogenology 2005;63:411-21.

95. Gulliver CE, Friend MA, King BJ, Clayton ET. The role of omega-3 polyunsaturated fatty acids in reproduction of sheep and cattle. Anim Reprod Sci 2012;131:9-22.

96. De Graaf SP, Peake K, Maxwell WMC, O'Brien JK, Evans G. Influence 
of supplementing diet with oleic and linoleic acid on the freezing ability and sex-sorting parameters of ram semen. Livest Sci 2007; 110:166-73.

97. Alizadeh AR, Esmaeili V, Shahverdi A, Rashidi L. Dietary fish oil can change sperm parameters and fatty acid profiles of ram sperm during oil consumption period and after removal of oil source. Cell J 2014;16:289-98.

98. Adeel M, Ijaz A, Aleem M, et al. Improvement of liquid and frozenthawed semen quality of Nili-Ravi buffalo bulls (Bubalus bubalis) through supplementation of fat. Theriogenology 2009;71:1220-5.

99. Gholami H, Chamani M, Towhidi A, Fazeli MH. Effect of feeding a docosahexaenoic acid-enriched nutriceutical on the quality of fresh and frozen-thawed semen in Holstein bulls. Theriogenology 2010;74:1548-58.

100. Khan MIR, Ijaz A. Assessing undiluted, diluted and frozen-thawed Nili-Ravi buffalo bull sperm by using standard semen assays. Ital J Anim Sci 2007;6:784-7.

101. Milovanov VK, Golubj VS. Effect of special nutrition of rams on the lipid content of spermatozoa and on fertility results after insemination. Zhivotnovodstvo 1973;11:78-80.

102. Calisici O. Investigation of antioxidative capacity in bovine seminal plasma-effects of omega-3 fatty acid. Hanover: Bibliothek der Tierarztlichen Hochschule hanover 2010;37-8.

103. Lyberg AM, Fasoli E, Adlercreutz P. Monitoring the oxidation of docosahexaenoic acid in lipids. Lipids 2005;40:969-79.

104. Gholami H, Chamani M, Towhidi A, Fazeli MH. Improvement of semen quality in holstein bulls during heat stress by dietary supplementation of omega-3 fatty acids. Int. J Fertil Steril 2011;4:160-7.

105. Strzezek J, Fraser L, Kuklińska M, Dziekońska A. Effects of dietary supplementation with polyunsaturated fatty acids and antioxidants on biochemical characteristics of boar semen. Reprod Biol 2004;4: 271-87.

106. Aitken RJ. Reactive oxygen species and human sperm function. In: Bacetti B, editor. Comparative spermatology 20 years after. NY, USA: Raven Press; 1991. p. 787-92.

107. Jahanian E, Nanaei HA, Kor NM. Influence of oxidative stress on sperm quality in animal. Int J Bio Sci 2014;4:10-6.

108. De Lamirande E, Tsai C, Harakat A, Gagnon C. Involvement of reactive oxygen species in human sperm arcosome reaction induced by A23187, Iysophosphatidylcholine, and biological Fluid ultrafilttates. J Androl 1998;19:585-94.

109. Goncalves FS, Barretto LSS, Arruda RP, Perri SHV, Mingoti GZ. Effect of antioxidants during bovine in vitro fertilization procedures on spermatozoa and embryo development. Reprod Domest Anim 2010;45:129-35.

110. Balercia G, Moretti S, Vignini A, et al. Role of nitric oxide concentrations on human sperm motility. J Androl 2004;25:245-9.

111. Donnelly ET, Lewis SE, Thompson W, Chakravarthy U. Sperm nitric oxide and motility: The effects of nitric oxide synthase stimulation and inhibition. Mol Hum Reprod 1997;3:755-62.

112. Kwon WS, Oh SA, Kim YJ, et al. Proteomic approaches for profiling negative fertility markers in inferior boar spermatozoa. Sci Rep 2015;
5:13821

113. Kwon WS, Rahman MS, Ryu DY, Park YJ, Pang MG. Increased male fertility using fertility-related biomarkers. Sci Rep 2015;5: 15654.

114. Tavilani H, Goodarzi MT, Doosti M, et al. Relationship between seminal antioxidant enzymes and the phospholipid and fatty acid composition of spermatozoa. Reprod Biomed Online 2008;16:649-56.

115. Park YJ, Kwon WS, Oh SA, Pang MG. Fertility-related proteomic profiling bull spermatozoa separated by percoll. J Proteome Res 2012; 11:4162-8.

116. Cocco T, Di Paola M, Papa S, Lorusso M. Chemical modification of the bovine mitochondrial $b c 1$ complex reveals critical acidic residues involved in the proton pumping activity. Biochemistry 1998;37:2037-43.

117. Shibanuma M, Inoue A, Ushida K, et al. Importance of mitochondrial dysfunction in oxidative stress response: A comparative study of gene expression profiles. Free Radic Res 2011;45:672-880.

118. Aguilera-Aguirre, Bacsi LA, Saavedra-Molina A, et al. Mitochondrial dysfunction increases allergic airway inflammation. J Immunol 2009;183:5379-87.

119. Manjunath P, Therien I. Role of seminal plasma phospholipid-binding proteins in sperm membrane lipid modification that occurs during capacitation. J Reprod Immunol 2002;53:109-19.

120. Doreau M, Chilliard Y. Digestion and metabolism of dietary fat in farm animals. Br J Nutr 1997;78:S15-S35.

121. NRC (National Research Council). Nutrient requirements of dairy cattle. 7th edn. Washington, DC: National Academy of Sciences; 2001.

122. Syadati SA, Aghsaghali AM, Fathi H, Davuodi J. Importance essential fatty acids (n-6 and n-3) in animal nutrition: I: Ruminant. Ann Biol Res 2012;3:1161-76.

123. Ashes JR, Siebert BD, Gulati SK, Cuthbertson AZ, Scott TW. Incorporation of $n-3$ fatty acids of fish oil into tissue and serum lipids of ruminants. Lipids 1992;27:629-31.

124. Ashes JR, Gulati SK, Cook LJ, Scott TW, Donnelly JB. Assessing the biological effectiveness of protected lipid supplements for ruminants. J Am Oil Chem Soc 1979;56:552-7.

125. Putnam D, Garrett J, Kung L. Evaluation key to use of rumen-stable encapsulates. Feedstuffs 2003;75:10-2.

126. Fotouhi N, Jenkins TC. Resistance of fatty acyl amides to degradation and hydrogenation by ruminal microorganisms. J Dairy Sci 1992; 75:1527-32.

127. Jenkins TC, Palmquist DL. Effect of fatty acids or calcium soaps on rumen and total nutrient digestibility of dairy rations. J Dairy Sci 1984;67:978-86.

128. Sukhija PS, Palmquist DL. Dissociation of calcium soaps of longchain fatty-acids in rumen fluid. J Dairy Sci 1990;73:1784-7.

129. Naik PK, Saijpaul S, Rani N. Evaluation of rumen protected fat prepared by fusion method. Anim Nutr Feed Technol 2007;7:95-101.

130. Simopoulos AP. Omega-3 fatty acids in health and disease and in growth and development. Am J Clin Nutr 1991;54:438-63.

131. Am-in N, Kirkwood RN, Techakumphu M, Tantasuparuk W. Lipid profiles of sperm and seminal plasma from boars having normal or low sperm motility. Theriogenology 2011;75:897-903. 
132. Liu Q, Zhou YF, Duan RJ, Wei HK, Jiang SW, Peng J. Effects of dietary $\mathrm{n}-6: \mathrm{n}-3$ fatty acid ratio and vitamin $\mathrm{E}$ on semen quality, fatty acid composition and antioxidant status in boars. Anim Reprod Sci 2015; 162:11-9.

133. Yan L, Bai X, Fang Z, et al. Effect of different dietary omega-3/omega-6 fatty acid ratios on reproduction in male rats. Lipids Heath Dis 2013; 12:33.

134. Hazim J, Al-Daraji HA, Al-Mashadani WK, et al. Effect of n-3 and $\mathrm{n}-6$ fatty acid supplemented diets on semen quality in Japanese quail (Coturnix coturnix japonica). Int J Poult Sci 2010;9:656-63.

135. Grady ST, Cavinder CA, Brinsko SP, et al. Dietary supplementation of two varying sources of n-3 fatty acids and subsequent effects on fresh, cooled, and frozen seminal characteristics of stallions. Prof Anim Sci 2009;25:768-73.

136. Al-Daraji HJ, Al-Mashadani HA, Al-Hayani WK, Al-Hassani AS, Mirza HA. Effect of n-3 and n-6 fatty acid supplemented diets on semen quality in Japanese quail (Coturnix coturnix japonica). Int J Poult Sci 2010;9:656-63.

137. Woods VB, Fearon AM. Dietary sources of unsaturated fatty acids for animals and their transfer into meat, milk and eggs: A review. Livest Sci 2009;126:1-20. 